INDONESIA ACCOUNTING JOURNAL

VOLUME 2, NUMBER 2, YEAR 2020

${ }^{1}$ Corresponding author

Program Studi Magister Akuntansi

Fakultas Ekonomi dan Bisnis

Universitas Mataram

Jl. Majapahit No.62 Kampus UNRAM

Mataram, Indonesia, 83125

E-mail: olien.kayllasabri@gmail.com

${ }^{2,3}$ Program Studi Magister Akuntansi Fakultas Ekonomi dan Bisnis

Universitas Mataram

Jl. Majapahit No.62 Kampus UNRAM

Mataram, Indonesia, 83125

Article info:

Received 10 June 2020

Accepted 5 July 2020

Available online 6 July 2020

Keywords: reliability; timeliness; accounting; financial reporting; human resources quality; utilization of information technology; accounting internal control; financial control JEL Classification: H11, H83, M48 DOI: http://doi.org/10.32400/iaj.28818

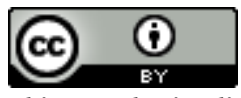

This work is licensed under a Creative Commons

Attribution 4.0

\section{Faktor-faktor yang mempengaruhi keandalan dan ketepatan waktu pelaporan keuangan pada Drganisasi Perangkat Daerah Kabupaten Sumbawa Barat}

\author{
Een Samawati Miharja ${ }^{1}$ \\ Lilik Handajani ${ }^{2}$ \\ Lalu M. Furkan ${ }^{3}$
}

\begin{abstract}
This study aims to provide empirically the effect of the human resources quality, utilization of information technology, accounting internal control, and financial control on reliability and timeliness of financial reporting on Local Government of West Sumbawa. The sample of this study is 76 respondents that work as civil servants at finance departments of 38 units at Local Government of West Sumbawa which taken by purposive sampling. This study shows that human resources quality, internal control of accounting, and financial control have positive and significant effect on reliability of financial reporting. This study also reports that human resources quality, utilization of information technology, accounting internal control, and financial control do not have effect on timeliness of financial reporting. On those findings, this study implies that the agency theory is consistent with the efforts of Local Government of West Sumbawa in term to present reliable financial information. Otherwise, this study implies that the compliance theory is not applicable to Local Government of West Sumbawa as human resources quality, utilization of information technology, accounting internal control, and financial control are not as determinants of timeliness on their financial reporting.
\end{abstract}

International License.

\section{Pendahuluan}

Keandalan dan ketepatan waktu informasi laporan keuangan merupakan wujud pertanggungjawaban pengelolaan keuangan publik dan sesuai dengan Peraturan Pemerintah Nomor 24 Tahun 2005 yang merupakan dua unsur nilai informasi yang penting terkait dengan pengambilan keputusan berbagai pihak. Sejak diberlakukannya Undang-Undang Keuangan Negara tahun 2003 yang secara khusus menggunakan anggaran berbasis kinerja pada satuan kerja pemerintah, maka pertanggungjawaban pengelolaan keuangan yang diwujudkan dalam laporan keuangan dituntut keandalan dan ketepatan waktunya.

Beberapa bukti empiris menunjukkan faktor-faktor yang berperan penting dalam menentukan keandalan pelaporan keuangan. Kualitas sumber daya manusia adalah merupakan salah satu faktor penting yang dapat mempengaruhi keandalan pelaporan keuangan dari pemerintah daerah (Andriani, 2010; Fransiska et al., 2015; Safitri, 2016). Selain itu, dukungan optimal atas pemanfaatan teknologi informasi dalam hal pemrosesan data dan informasi juga merupakan salah satu faktor yang dapat mempengaruhi keandalan pelaporan keuangan (Ariesta, 2013; Azlan et al., 2015; Yusrawati dan Cahyanti, 2016). Faktor lainnya adalah pengendalian intern akuntansi, dimana pengendalian intern yang baik atas pencatatan akuntansi dianggap mampu menciptakan keandalan pelaporan akuntansi (Indriasari dan Nahartyo, 2008; 
Arfianti dan Kawedar, 2011; Kosegeran et al., 2016). Faktor penting lainnya adalah pengawasan keuangan dimana dengan adanya pengawasan atas kepatuhan pada peraturan yang berlaku dapat menjamin keandalan pelaporan keuangan (Marda et al., 2014; Azlan et al., 2015; Setianingrum, 2016). Selain keandalan pelaporan keuangan, ketepatan waktu pelaporan keuangan merupakan hal penting guna menjamin tersedianya informasi bagi masyarakat umum. Seperti halnya keandalan pelaporan keuangan, maka kualitas sumber daya manusia (Sembiring, 2013; Prasetyo, 2015; Safitri, 2016), pemanfaatan teknologi informasi (Andriani, 2010; Arfianti dan Kawedar, 2011; Rosalin dan Kawedar, 2011), pengendalian intern akuntansi (Rachmawati, 2014; Kosegeran et al., 2016; Marlinawati dan Wardani, 2018), dan pengawasan keuangan (Mustafa et al., 2011; Trisaputra, 2013) juga turut menentukan ketepatan waktu pelaporan keuangan.

Pada tahun 2017, Kabupaten Sumbawa Barat mendapat opini Wajar Tanpa Pengecualian (WTP), namun dari segi sistem pengendalian intern Badan Pemeriksa Keuangan (BPK) menemukan adanya kelemahan sistem dan prosedur pengendalian intern dalam penyusunan laporan keuangan antara lain penerimaan dan pengeluaran dana Bantuan Operasional Sekolah (BOS) belum dianggarkan dalam Anggaran Pendapatan dan Belanja Daerah (APBD) dan Pengelolaan Aset Tetap belum dilakukan secara tertib. Pihak BPK menyarankan pada Kepala Bidang Aset untuk lebih optimal dalam melakukan inventarisasi Barang Milik Daerah (BMD). Dari segi kepatuhan, Badan Pemeriksa Keuangan (BPK) menemukan adanya ketidakpatuhan terhadap peraturan perundang-undangan dalam pengelolaan keuangan Negara, antara lain pembayaran jasa konsultansi belum berdasarkan bukti pembayaran riil dan 5 (lima) paket pekerjaan tidak dilaksanakan kontrak sehingga Badan Pemeriksa Keuangan (BPK) memerintahkan Pejabat Pembuat Komitmen (PPK) dan Pejabat Pembuat Teknis Kegiatan (PPTK) untuk lebih optimal dalam melaksanakan tugasnya melakukan verifikasi dokumen, dan pengajuan pembayaran dengan bukti yang riil dan hasil kerja yang telah ditetapkan. Badan Pemeriksa Keuangan (BPK) juga memerintahkan kepala Organisasi Perangkat Daerah (OPD) terkait agar lebih optimal dalam melakukan pengendalian dan pengawasan atas kegiatan yang menjadi tanggung jawab (https://www.jariungu.com/lap bpk detail to publik.php?idLap=15033). Berdasarkan kesenjangan riset, maka tujuan penelitian ini adalah untuk memberikan bukti empiris atas pengaruh kualitas sumber daya manusia, pemanfaatan teknologi informasi, pengendalian intern akuntansi, dan pengawasan keuangan terhadap keandalan dan ketepatan waktu pelaporan keuangan Organisasi Perangkat Daerah di Pemerintah Kabupaten Sumbawa Barat.

\section{Tinjauan pustaka}

\section{Teori keagenan (agency theory)}

Teori keagenan (agency theory) merupakan teori yang menyatakan secara umum bahwa hubungan keagenan merupakan suatu kontrak dimana satu orang atau lebih (prinsipal) memerintah orang lain (agen) untuk melakukan suatu jasa atas nama prinsipal serta memberi wewenang kepada agen untuk membuat keputusan yang terbaik bagi prinsipal (Jensen dan Meckling, 1976). Akuntabilitas publik dapat dimaknai dengan adanya kewajiban pihak pemegang amanah (agen) untuk memberikan pertanggungjawaban, menyajikan, melaporkan, dan mengungkapkan segala aktivitas dan kegiatan yang menjadi tanggungjawabnya kepada pihak pemberi amanah (principal) yang memiliki hak dan kewenangan untuk meminta pertanggungjawaban tersebut (Haryanto et al., 2007). Implikasi teori keagenan dari sudut perspektif akuntansi sektor publik khususnya dalam akuntansi pemerintahan adalah bahwa pemerintah dalam perannya sebagai agen mempunyai kewajiban menyajikan laporan keuangan yang mengandung informasi transparan dan akuntabel bagi pengguna informasi keuangan pemerintah dalam perannya 
sebagai prinsipal untuk menilai transparansi dan akuntabilitas laporan keuangan tersebut sekaligus menggunakan informasi keuangan tersebut untuk kepentingan pengambilan keputusan dalam bidang ekonomi, sosial, dan politik (Rosalin dan Kawedar, 2011).

\section{Teori kepatuhan (compliance theory)}

Menurut Kelman (1958), kepatuhan (compliance) diartikan sebagai suatu kepatuhan yang didasarkan pada harapan akan suatu imbalan dan usaha untuk menghindarkan diri dari hukuman yang akan mungkin terjadi. Kepatuhan pemerintah dengan menggunakan sistem akuntansi keuangan daerah yang berpedoman kepada Standar Akuntansi Pemerintah (SAP). Menurut Rosalin dan Kawedar (2011), implikasi teori kepatuhan merujuk pada Standar Akuntansi Pemerintah (SAP) yang merupakan pedoman yang wajib dipatuhi oleh pemerintah dalam menjalankan sistem dan prosedur pencatatan akuntansi.

\section{Konsep variabel}

Keandalan (reliability). Berdasarkan Peraturan Pemerintah Nomor 71 Tahun 2010, keandalan pelaporan keuangan merupakan informasi dalam laporan keuangan bebas dari pengertian yang menyesatkan dan kesalahan material, menyajikan setiap fakta secara jujur, serta dapat diverifikasi, dimana informasi yang andal memenuhi karakteristik penyajian jujur, dapat diverifikasi, dan netralitas. Keandalan pada umumnya dikaitkan dengan penyajian setiap setiap fakta informasi dan laporan keuangan dapat diverifikasi kebutuhan umum yang disajikan secara wajar dan jujur dan tersajinya neraca, laporan realisasi anggaran, catatan atas laporan keuangan disajikan, dan informasi yang disajikan dapat diuji dan di rekonsiliasi dilakukan secara periodik antara catatan akuntansi dengan catatan bank (Indriasari dan Nahartyo, 2008).

Ketepatan waktu (timeliness). Ketepatan waktu laporan keuangan adalah tersedianya informasi bagi pembuat keputusan pada saat dibutuhkan sebelum informasi tersebut kehilangan kekuatan untuk mempengaruhi keputusan (Peraturan Pemerintah Nomor 71 Tahun 2010). Penyampaian informasi sedini mungkin dapat dipakai sebagai dasar dalam pengambilan keputusan ekonomi dan mencegah agar terlambatnya pembuatan keputusan tersebut dapat diartikan sebagai tepat waktu (Rachmawati, 2014).

Kualitas sumber daya manusia. Sumber daya manusia dalam menyusun laporan keuangan pemerintah daerah haruslah berkompeten dan independen serta mampu bertanggungjawab atas laporan yang telah disusunnya (Fransiska et al., 2015). Menurut Winidyaningrum dan Rahmawati (2010), kapasitas sumber daya manusia adalah kemampuan seseorang atau individu, suatu organisasi (kelembagaan) atau suatu sistem untuk melaksanakan fungsi-fungsi atau kewenangannya untuk mencapai tujuannya secara efektif dan efisien.

Pemanfaatan teknologi informasi. Mustafa et al. (2011) secara umum menjelaskan bahwa pemanfaatan teknologi informasi dapat ditinjau dari: (a) pemanfaatan perangkat (kelengkapan yang mendukung terlaksananya penggunaan teknologi informasi meliputi perangkat lunak, keras dan sistem jaringan); (b) pemrosesan dan penyimpanan (pemanfaatan teknologi informasi untuk pengelolaan data keuangan serta sistematis dan menyeluruh); dan (c) perawatan (adanya jadwal pemeliharaan peralatan perangkat teknologi informasi secara teratur guna mendukung kelancaran pekerjaan).

Pengendalian intern. Peraturan Pemerintah Nomor 60 Tahun 2008 tentang Sistem Pengendalian Intern Pemerintah menyatakan bahwa sistem pengendalian intern adalah proses yang integral pada tindakan dan kegiatan yang dilakukan secara terus menerus oleh pimpinan dan seluruh pegawai untuk memberikan keyakinan memadai atas tercapainya tujuan organisasi melalui kegiatan yang efektif dan efisien, keterandalan pelaporan keuangan, pengamanan aset negara, dan ketaatan terhadap peraturan perundang-undangan. Menurut Indriasari dan Nahartyo (2008), pengendalian intern meliputi struktur organisasi, metoda, dan ukuran-ukuran yang 
dikoordinasikan untuk menjaga kekayaan organisasi, mengecek ketelitian dan keandalan data akuntansi, mendorong efisiensi, dan dipatuhinya kebijakan pimpinan.

Pengawasan keuangan. Pengawasan keuangan yang dilakukan juga diarahkan untuk mendapatkan keyakinan yang memadai terhadap efektifitas dan efisiensi organisasi, keterandalan pelaporan keuangan dan kepatuhan terhadap peraturan (Yosa, 2010). Definisi pengawasan menurut Keputusan Presiden Nomor 74 tahun 2001 tentang Tata Cara Pengawasan Penyelengaraan Pemerintah Daerah dalam Pasal 16 menyebutkan bahwa pengawasan pemerintah daerah adalah proses kegiatan yang ditujukan untuk menjamin agar pemerintah daerah berjalan sesuai dengan rencana dan ketentuan peraturan perundang-undangan yang berlaku.

\section{Hubungan antar variabel dan pengembangan hipotesis}

Kualitas sumber daya manusia dan keandalan pelaporan keuangan. Kualitas sumber daya manusia akan berimplikasi pada keandalan pelaporan keuangan, dimana kemampuan seorang pegawai baik dalam tingkatan individu, organisasi, maupun sistem dalam melaksanakan fungsi-fungsi atau kewenangannya untuk mencapai tujuannya secara efektif dan efisien dan bertanggung jawab dalam melaksanakan tugasnya sehingga akan memberikan pengaruh terhadap keandalan pelaporan keuangan (Winidyaningrum dan Rahmawati, 2010). Menurut Tjiptoherijanto (2001) dalam Indriasari dan Nahartyo (2008) menyatakan bahwa untuk menilai kapasitas dan kualitas sumber daya manusia dalam melaksanakan suatu fungsi, termasuk akuntansi, dapat dilihat dari level of responsibility dan kualitas sumber daya tersebut. Andriani (2010), Winidyaningrum dan Rahmawati (2010), Mustafa et al. (2011), Hullah et al. (2012), Ariesta (2013), Sembiring (2013), Marda et al. (2014), Sari dan Witono (2014), Azlan et al. (2015), Fransiska et al. (2015), Kosegeran et al. (2016), Safitri (2016), Setianingrum (2016),
Yusrawati dan Cahyanti (2016), dan Putra (2017) menunjukkan bahwa kualitas sumber daya manusia signifikan mempengaruhi keandalan pelaporan keuangan. Sebaliknya, Indriasari dan Nahartyo (2008), Arfianti dan Kawedar (2011), Rosalin dan Kawedar (2011), Rachmawati (2014), dan Prasetyo (2015) menunjukkan bahwa kualitas sumber daya manusia tidak signifikan mempengaruhi keandalan pelaporan keuangan. Berdasarkan penjelasan tersebut maka dapat ditarik hipotesis sebagai berikut: H1: Kualitas sumber daya manusia memiliki pengaruh positif terhadap keandalan pelaporan keuangan.

Pemanfaatan teknologi informasi dan keandalan pelaporan keuangan. Indriasari dan Nahartyo (2008) menyatakan bahwa perkembangan teknologi informasi tidak hanya dimanfaatkan pada organisasi bisnis tetapi juga pada organisasi sektor publik, termasuk pemerintahan. Peraturan Pemerintah Nomor 56 Tahun 2005 tentang Sistem Informasi Keuangan Daerah menyebutkan bahwa untuk menindak lanjuti terselenggaranya proses pembangunan yang sejalan dengan prinsip tata kelola pemerintahan yang baik (good governance), maka pemerintah dan pemerintah daerah berkewajiban untuk mengembangkan dan memanfaatkan kemajuan teknologi informasi untuk meningkatkan kemampuan mengelola keuangan daerah, dan menyalurkan informasi keuangan daerah kepada pelayanan publik. Indriasari dan Nahartyo (2008), Andriani (2010), Winidyaningrum dan Rahmawati (2010), Rosalin dan Kawedar (2011), Hullah et al. (2012), Ariesta (2013), Sembiring (2013), Sari dan Witono (2014), Azlan et al. (2015), Fransiska et al. (2015), Prasetyo (2015), Kosegeran et al. (2016), Safitri (2016), Setianingrum (2016), Yusrawati dan Cahyanti (2016), dan Putra (2017) menunjukkan bahwa pemanfaatan teknologi informasi signifikan mempengaruhi keandalan pelaporan keuangan. Sebaliknya, Arfianti dan Kawedar (2011), Mustafa et al. (2011), Marda et al. (2014), dan Rachmawati (2014) menunjukkan bahwa pemanfaatan teknologi informasi tidak signifikan 
mempengaruhi keandalan pelaporan keuangan. Berdasarkan penjelasan tersebut maka dapat ditarik hipotesis sebagai berikut: H2: Pemanfaatan teknologi informasi memiliki pengaruh positif terhadap keandalan pelaporan keuangan.

Pengendalian intern akuntansi dan keandalan pelaporan keuangan. Pengendalian intern meliputi struktur organisasi, metoda, dan ukuran-ukuran yang dikoordinasikan untuk menjaga kekayaan organisasi, mengecek ketelitian dan keandalan data akuntansi, mendorong efisiensi, dan dipatuhinya kebijakan pimpinan (Indriasari dan Nahartyo, 2008). Menurut Noviyanti 2004 dalam Winidyaningrum dan Rahmawati (2010), pengendalian intern yang lemah menyebabkan tidak dapat terdeteksinya kecurangan atau ketidak-akuratan proses akuntansi sehingga bukti audit yang diperoleh dari data akuntansi menjadi tidak kompeten. Indriasari dan Nahartyo (2008), Winidyaningrum dan Rahmawati (2010), Arfianti dan Kawedar (2011), Rosalin dan Kawedar (2011), Ariesta (2013), Sembiring (2013), Rachmawati (2014), Sari dan Witono (2014), Azlan et al. (2015), Prasetyo (2015), Kosegeran et al. (2016), Setianingrum (2016), Yusrawati dan Cahyanti (2016), dan Putra (2017) menunjukkan bahwa pengendalian intern akuntansi signifikan mempengaruhi keandalan pelaporan keuangan. Sebaliknya, Mustafa et al. (2011) menunjukkan bahwa pengendalian intern akuntansi tidak signifikan mempengaruhi keandalan pelaporan keuangan. Berdasarkan penjelasan tersebut maka dapat ditarik hipotesis sebagai berikut:

H3: Pengendalian intern akuntansi memiliki pengaruh positif terhadap keandalan pelaporan keuangan.

Pengawasan keuangan dan keandalan pelaporan keuangan. Pengawasan merupakan suatu upaya yang sistematik untuk menetapkan kinerja standar pada perencanaan untuk merancang sistem umpan balik informasi untuk membandingkan kinerja aktual dengan standar yang telah ditentukan, untuk menetapkan apakah telah terjadi suatu penyimpangan, serta untuk mengambil tindakan perbaikan yang diperlukan untuk menjamin bahwa sumber data organisasi atau pemerintahan telah digunakan seefektif dan seefisien mungkin guna mencapai tujuan organisasi atau pemerintahan (Yosa, 2010). Mustafa et al. (2011), Marda et al. (2014), Azlan et al. (2015), Fransiska et al. (2015), Setianingrum (2016), dan Putra (2017) menunjukkan bahwa pengawasan keuangan signifikan mempengaruhi keandalan pelaporan keuangan. Sebaliknya, Arfianti dan Kawedar (2011) menunjukkan bahwa pengawasan keuangan tidak signifikan mempengaruhi keandalan pelaporan keuangan. Berdasarkan penjelasan tersebut maka dapat ditarik hipotesis sebagai berikut: H4: Pengawasan keuangan memiliki pengaruh positif terhadap keandalan pelaporan keuangan.

Kualitas sumber daya manusia dan ketepatan waktu pelaporan keuangan. Sumber daya yang berkualitas dapat menghemat waktu pembuatan laporan keuangan. Hal ini disebabkan karena sumber daya manusia tersebut telah mengetahui dan memahami apa yang akan dikerjakan dengan baik sehingga penyajian laporan keuangan bisa tepat waktu (Sembiring, 2013). Semakin cepat waktu penyajian laporan keuangan maka semakin baik untuk pengambilan keputusan (Mardiasmo, 2002). Indriasari dan Nahartyo (2008), Arfianti dan Kawedar (2011), Mustafa et al. (2011), Ariesta (2013), Sembiring (2013), Sari dan Witono (2014), Prasetyo (2015), Kosegeran et al. (2016), Safitri (2016), dan Marlinawati dan Wardani (2018) menunjukkan bahwa kualitas sumber daya manusia signifikan mempengaruhi ketepatan waktu pelaporan keuangan. Sebaliknya, Andriani (2010), Winidyaningrum dan Rahmawati (2010), Rosalin dan Kawedar (2011), dan Rachmawati (2014) menunjukkan bahwa kualitas sumber daya manusia tidak signifikan mempengaruhi ketepatan waktu pelaporan keuangan. Berdasarkan penjelasan tersebut maka dapat ditarik hipotesis sebagai berikut:

H5: Kualitas sumber daya manusia memiliki pengaruh positif terhadap ketepatan waktu pelaporan keuangan. 


\section{Pemanfaatan teknologi informasi dan ketepatan waktu pelaporan} keuangan. Ariesta (2013) membuktikan bahwa pemanfaatan teknologi informasi adalah manfaat yang diharapkan oleh pengguna teknologi informasi dalam melaksanakan tugasnya. Sistem akuntansi di pemerintah daerah sudah pasti memiliki transaksi yang kompleks dan oleh sebab itu maka pemanfaatan teknologi informasi akan sangat membantu mempercepat proses pengelolaan data transaksi dan penyajian laporan keuangan sehingga laporan keuangan tersebut tidak kehilangan nilai informasi yaitu ketepatwaktuan (Ariesta, 2013). Indriasari dan Nahartyo (2008), Andriani (2010), Winidyaningrum dan Rahmawati (2010), Arfianti dan Kawedar (2011), Rosalin dan Kawedar (2011), Ariesta (2013), Sembiring (2013), Trisaputra (2013), Sari dan Witono (2014), Prasetyo (2015), Kosegeran et al. (2016), dan Safitri (2016) menunjukkan bahwa pemanfaatan teknologi informasi signifikan mempengaruhi ketepatan waktu pelaporan keuangan. Sebaliknya, Mustafa et al. (2011), Rachmawati (2014), dan Marlinawati dan Wardani (2018) menunjukkan bahwa pemanfaatan teknologi informasi tidak signifikan mempengaruhi ketepatan waktu pelaporan keuangan. Berdasarkan penjelasan tersebut maka dapat ditarik hipotesis sebagai berikut:

H6: Pemanfaatan teknologi informasi memiliki pengarub positif terhadap ketepatan waktu pelaporan keuangan.

Pengendalian intern akuntansi dan ketepatan waktu pelaporan keuangan. Menurut Sembiring (2013), semakin tinggi pengendalian intern dalam instansi pemerintah maka dapat meningkatkan ketepatan waktu pelaporan keuangan sesuai dengan ketaatan terhadap peraturan perundang-undangan. Sistem pengendalian intern merupakan sistem pengendalian yang harus diterapkan dalam lingkungan pemerintahan untuk menciptakan pengelolaan keuangan daerah yang akuntabel (Sembiring, 2013). Sembiring (2013), Rachmawati (2014), Sari dan Witono (2014), Kosegeran et al. (2016), dan
Marlinawati dan Wardani menunjukkan bahwa pengendalian intern akuntansi signifikan mempengaruhi ketepatan waktu pelaporan keuangan. Sebaliknya, Mustafa et al. (2011), dan Rosalin dan Kawedar (2011) menunjukkan bahwa pengendalian intern akuntansi tidak signifikan mempengaruhi ketepatan waktu pelaporan keuangan. Berdasarkan penjelasan tersebut maka dapat ditarik hipotesis sebagai berikut:

H7: Pengendalian intern akuntansi memiliki pengarub positif terbadap ketepatan waktu pelaporan keuangan.

\section{Pengawasan keuangan dan} ketepatan waktu pelaporan keuangan. Pengawasan merupakan suatu upaya yang sistematik untuk menetapkan kinerja standar pada perencanaan untuk merancang sistem umpan balik informasi untuk membandingkan kinerja aktual dengan standar yang telah ditentukan guna menentukan apakah telah terjadi suatu penyimpangan atau tidak, serta untuk mengambil tindakan perbaikan yang diperlukan untuk menjamin bahwa sumber data organisasi atau pemerintahan telah digunakan seefektif dan seefisien mungkin guna mencapai tujuan organisasi atau pemerintahan (Yosa, 2010). Mustafa et al. (2011), dan Trisaputra (2013) menunjukkan bahwa pengawasan keuangan signifikan mempengaruhi ketepatan waktu pelaporan keuangan, sedangkan Arfianti dan Kawedar (2011) menunjukkan bahwa pengawasan keuangan tidak mempengaruhi ketepatan waktu pelaporan keuangan. Berdasarkan penjelasan tersebut maka dapat ditarik hipotesis sebagai berikut:

H8: Pengawasan keuangan memiliki pengarub positif terbadap ketepatan waktu pelaporan keuangan.

\section{Metode penelitian}

Penelitian ini menggunakan pendekatan kuantitatif dengan jenis penelitian eksplanatori. Lokasi penelitian ini dilakukan di wilayah Kabupaten Sumbawa Barat, khususnya Organisasi Perangkat Daerah (OPD) yang ada di lingkungan Pemerintah Kabupaten Sumbawa Barat. Populasi dalam 
penelitian ini adalah aparatur negara pada 39 OPD di Sub Bagian Akuntansi/Tata Usaha Keuangan Pemerintah Kabupaten Sumbawa Barat yakni yang menjabat sebagai Bendahara dan Kasubag Akuntansi/Tata Usaha Keuangan sehingga penentuan sampel ditentukan dengan menggunakan metode non probability sampling dengan pendekatan purposive sampling. Pemerintah Kabupaten Sumbawa Barat memiliki 39 OPD sehingga penelitian ini mengambil 2 sampel untuk masing-masing OPD untuk mengisi kuesioner yaitu Bendahara dan Kasubag Akuntansi/Tata Usaha Keuangan. Jumlah sampel berdasarkan kuesioner yang berhasil dikumpulkan adalah sebanyak 76 kuesioner yang berasal dari 38 OPD.

Variabel independen yang digunakan dalam penelitian ini yaitu kualitas sumber daya manusia (KSDM), pemanfaatan teknologi informasi (PTI), pengendalian intern akuntansi (PIA), dan pengawasan keuangan (PK). Variabel dependen yang digunakan dalam penelitian ini yaitu keandalan (reliability) dan ketepatan waktu (timeliness) atas pelaporan keuangan (masingmasing disimbolkan dengan KPK dan TPK). Variabel keandalan diukur dengan indikator yang diukur dengan skala Likert 5 (lima) poin yaitu: (1) penyajian setiap fakta informasi; (2) laporan keuangan dapat diverifikasi; dan (3) kebutuhan umum. Variabel ketepatan waktu diukur dengan indikator yang diukur dengan skala Likert 5 (lima) poin yaitu: (1) tersedianya informasi saat dibutuhkan; (2) laporan yang sistematis dan teratur: dan (3) penyampaian laporan yang teratur dan sistematis. Variabel kualitas sumber daya manusia diukur dengan indikator yang diukur dengan skala Likert 5 (lima) poin yaitu: (1) kualifikasi pendidikan; (2) peran dan fungsi staf; (3) pedoman prosedur dan proses akuntansi; (4) sumber daya pendukung operasional; dan (5) penguasaan dan pengembangan keahlian. Variabel pemanfaatan teknologi informasi diukur dengan indikator yang diukur dengan skala Likert 5 (lima) poin yaitu: (1) computer (software dan hardware); dan (2) E-commerce. Variabel pengendalian intern akuntansi diukur dengan indikator yang diukur dengan skala Likert 5 (lima) poin yaitu: (1) sistem dan prosedur; (2) otorisasi; (3) formulir dan dokumen pencatatan; dan (4) pemisahan tugas. Variabel pengawasan keuangan diukur dengan indikator yang diukur dengan skala Likert (lima) poin yaitu: (1) pemerintah yang bersih dan bebas korupsi, kolusi, dan nepotisme: (2) pencatatan transaksi keuangan yang benar: (3) sistem pengawasan terhadap pelaksanaan tugas: dan (4) laporan keuangan disajikan sesuai SAP.

Teknik pengumpulan data dengan pengiriman kuesioner yang dilakukan secara survey dengan mendatangi staf pelaporan keuangan Organisasi Perangkat Daerah yang tersebar di Kabupaten Sumbawa Barat. Metode analisis data yang digunakan dalam penelitian ini adalah metode PLS-SEM dengan tahapan analisis menggunakan prosedur PLS-SEM berdasarkan Ghozali dan Latan (2015:47). Persamaan Outer Model Reflective dari penelitian ini disajikan sebagai berikut.

$$
\begin{aligned}
\text { KSDM }= & \lambda_{1} \mathrm{KSDM}_{1}+\lambda_{2} \mathrm{KSDM}_{2}+\lambda_{3} \mathrm{KSDM}_{3}+ \\
& \lambda_{4} \mathrm{KSDM}_{4}+\lambda_{5} \mathrm{KSDM}_{5}+\delta_{1} \\
\mathrm{PTI} & \lambda_{1} \mathrm{PTI}_{1}+\lambda_{2} \mathrm{PTI}_{2}+\delta_{2} \\
\mathrm{PIA} & \lambda_{1} \mathrm{PIA}_{1}+\lambda_{2} \mathrm{PIA}_{2}+\lambda_{3} \mathrm{PIA}_{3}+\delta_{3} \\
\mathrm{PK} & \lambda_{1} \mathrm{PK}_{1}+\lambda_{2} \mathrm{PK}_{2}+\lambda_{3} \mathrm{PK}_{3}+\delta_{4} \\
\mathrm{KPK} & \lambda_{1} \mathrm{KPK}_{1}+\lambda_{2} \mathrm{KPK}_{2}+\lambda_{3} \mathrm{KPK}_{3}+\delta_{5} \\
\text { TPK } & \lambda_{1} \mathrm{TPK}_{1}+\lambda_{2} \mathrm{TPK}_{2}+\lambda_{3} \mathrm{TPK}_{3}+\delta_{6}
\end{aligned}
$$

Persamaan model sruktural (inner model) dari penelitian ini disajikan sebagai berikut.

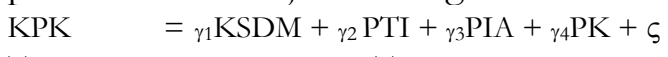

TPK $\quad={ }_{\gamma 5} \mathrm{KSDM}+{ }_{\gamma_{6} \mathrm{PTI}}+{ }_{\gamma 7 \mathrm{PIA}}+{ }_{\gamma 8} \mathrm{PK}+\varsigma$

Pada model-model tersebut $\lambda$ (lamda) adalah koefisien model pengukuran (loading weight), $\delta$ (delta) adalah galat pengukuran variabel eksogen, $\gamma_{1}-\gamma_{8}$ adalah gamma atau koefisien variabel, $\varsigma$ adalah zeta atau error terms atau galat model struktural, $\mathrm{KSDM}_{1-5}$ adalah indikator kualitas sumber daya manusia, $\mathrm{PTI}_{1-2}$ adalah indikator pemanfaatan teknologi informasi, PIA $_{1-3}$ adalah indikator pengendalian intern akuntansi, $\mathrm{PK}_{1-3}$ adalah indikator pengawasan keuangan, $\mathrm{KPK}_{1-3}$ adalah indikator keandalan pelaporan keuangan, dan $\mathrm{TPK}_{1-3}$ adalah ketepatan waktu (timeliness) pelaporan keuangan. 


\section{Hasil penelitian dan pembahasan \\ Hasil penelitian}

Tabel 1 menunjukkan bahwa nilai $R$ Square $\left(\mathrm{R}^{2}\right)$ adalah sebesar 0,506 atau 50,6\% yang memiliki arti bahwa konstruk KPK dapat dijelaskan oleh variabel KSDM, PTI, PIA, dan PK sebesar 50,6\% sedangkan 49,4\% dijelaskan oleh variabel lain diluar model yang dibangun dalam penelitian ini. Tabel 1 juga menunjukkan bahwa nilai $R$ Square $\left(\mathrm{R}^{2}\right)$ adalah sebesar 0,374 atau $37,4 \%$ yang memiliki arti bahwa konstruk TPK dapat dijelaskan oleh variabel KSDM, PTI, PIA, dan PK sebesar 37,4\% sedangkan $62,6 \%$ dijelaskan oleh variabel lain diluar model yang dibangun dalam penelitian ini. Tabel 1 menunjukkan bahwa nilai $\mathrm{Q}^{2}$ masing-masing sebesar 0,506 dan 0,374 yang melebihi nilai 0 (nol) sehingga model mempunyai predictive relevant.

Tabel 1. Nilai $\mathbf{R}-$ Square $\left(\mathrm{R}^{2}\right)$ dan Predictive Relevant $\left(\mathrm{Q}^{2}\right)$

\begin{tabular}{ccc}
\hline Variabel & $\mathbf{R}-$ Square $\left.\mathbf{( R}^{2}\right)$ & Predictive Relevant $\left(\mathbf{Q}^{2}\right)$ \\
\hline KPK & 0,506 & 0,506 \\
TPK & 0,374 & 0,374 \\
\hline
\end{tabular}

Uji konstruk discriminant validity pada model pengukuran indikator reflektif dinilai berdasarkan cross loading untuk setiap variabel serta membandingkan nilai masing-masing akar kuadrat Average Variance Extracted (AVE) terhadap nilai korelasi antar konstruk. Berdasarkan proses PLS algorithm maka nilai loading indicator ke konstruk yang diukur lebih besar dibandingkan loading indicator tersebut ke konstruk lainnya. Tabel 2 menunjukkan bahwa nilai cross loading memiliki loading indicator ke konstruk yang diukur lebih besar dibandingkan loading indicator ke konstruk lainnya dan nilai kuadrat AVE lebih besar dari korelasi antar konstruk indikator telah memenuhi discriminant validity dan dinyatakan valid.

Tabel 2. Akar kuadrat Average Variance Extracted (AVE) dan korelasi antar konstruk

\begin{tabular}{lcccccc}
\hline & KPK & KSDM & PIA & PK & PTI & TPK \\
\hline KPK & 0,871 & & & & & \\
KSDM & 0,521 & 0,885 & & & & \\
PIA & 0,578 & 0,443 & 0,781 & & & \\
PK & 0,602 & 0,398 & 0,589 & 0,909 & & \\
PTI & 0,310 & 0,452 & 0,465 & 0,437 & 0,833 & \\
TPK & 0,665 & 0,362 & 0,528 & 0,507 & 0,453 & 0,749 \\
\hline
\end{tabular}

Uji reliabilitas konstruk dilakukan untuk membuktikan akurasi, konsistensi dan ketepatan instrumen dalam mengukur konstruk dengan menggunakan composite reliability. Evaluasi reliabilitas konstruk pada model pengukuran indikator reflektif dilakukan dengan Cronbach's Alpha dan composite reliability. Namun demikian penggunaan Cronbach's Alpha untuk menguji konstruk akan memberikan nilai yang lebih rendah (underestimate) sehingga lebih disarankan untuk menggunakan composite reliability. Aturan praktis (rule of thumb) yang biasa digunakan untuk menilai reliabilitas konstruk yaitu nilai composite reliability harus lebih dari 0,7 (Ghozali dan Latan, 2015:75). Tabel 3 menunjukkan bahwa semua variabel memiliki nilai composite reliability diatas 0,70 sehingga semua variabel dalam model penelitian ini adalah reliabel. Proses uji validitas dan reliabilitas telah memenuhi syarat convergent validity dan composite reliability sehingga menghasilkan model pengukuran dengan indikator yang valid dan reliabel.

Tabel 3. Hasil uji reliabilitas

\begin{tabular}{ccc}
\hline Variabel & $\begin{array}{c}\text { Nilai composite } \\
\text { reliability }\end{array}$ & Keterangan \\
\hline KSDM & 0,915 & Reliabel \\
PTI & 0,818 & Reliabel \\
PIA & 0,822 & Reliabel \\
PK & 0,935 & Reliabel \\
KPK & 0,903 & Reliabel \\
TPK & 0,792 & Reliabel \\
\hline
\end{tabular}

Tabel 4 menyajikan hasil analisis model pengukuran (outer model) dari penelitian ini.

Tabel 4. Hasil persamaan model pengukuran (outer model)

\begin{tabular}{|c|c|}
\hline Variabel & $\begin{array}{c}\text { Model pengukuran (outer } \\
\text { model) }\end{array}$ \\
\hline $\begin{array}{l}\text { Kualitas sumber daya manusia } \\
\text { (८1) }\end{array}$ & $\begin{array}{l}\mathrm{KSDM}_{2}=0,923 \varsigma_{1}+\delta_{1} \\
\mathrm{KSDM}_{3}=0,927 \varsigma_{1}+\delta_{2} \\
\mathrm{KSDM}_{4}=0,799 \varsigma_{1}+\delta_{3}\end{array}$ \\
\hline $\begin{array}{l}\text { Pemanfaatan teknologi informasi } \\
\text { (५2) }\end{array}$ & $\begin{array}{l}\mathrm{PTI}_{1}=0,911 \varsigma_{2}+\delta_{4} \\
\mathrm{PTI}_{2}=0,746 \varsigma_{2}+\delta_{5}\end{array}$ \\
\hline $\begin{array}{l}\text { Pengendalian intern akuntansi } \\
\text { (५3) }\end{array}$ & $\begin{array}{l}\mathrm{PIA}_{1}=0,640 \zeta_{3}+\delta_{6} \\
\mathrm{PIA}_{2}=0,864 \varsigma_{3}+\delta_{7} \\
\mathrm{PIA}_{3}=0,821 \varsigma_{3}+\delta_{8}\end{array}$ \\
\hline Pengawasan keuangan $(\varsigma 4)$ & $\begin{array}{l}\mathrm{PK}_{1}=0,880 \zeta_{4}+\delta_{9} \\
\mathrm{PK}_{2}=0,939 \zeta_{4}+\delta_{10} \\
\mathrm{PK}_{3}=0,908 \zeta_{4}+\delta_{11}\end{array}$ \\
\hline $\begin{array}{l}\text { Keandalan pelaporan keuangan } \\
(\eta 1)\end{array}$ & $\begin{array}{l}\mathrm{KPK}_{1}=0,932 \varsigma_{1}+\eta_{1} \\
\mathrm{KPK}_{2}=0,912 \varsigma_{1}+\eta_{1} \\
\mathrm{KPK}_{3}=0,758 \varsigma_{1}+\eta_{1}\end{array}$ \\
\hline $\begin{array}{l}\text { Ketepatan waktu pelaporan } \\
\text { keuangan }(\eta 2)\end{array}$ & $\begin{aligned} \mathrm{TPK}_{1} & =0,664 \varsigma_{1}+\eta_{2} \\
\mathrm{TPK}_{2} & =0,818 \varsigma_{1}+\eta_{2} \\
\mathrm{TPK}_{3} & =0,756 \varsigma_{1}+\eta_{2}\end{aligned}$ \\
\hline
\end{tabular}


Berdasarkan prosedur PLS-SEM maka persamaan outer model reflective dari penelitian ini adalah sebagai berikut.

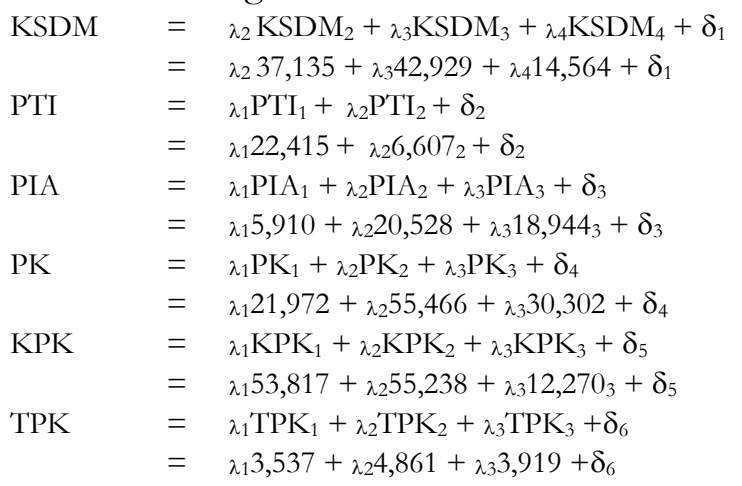

Tabel 5 menyajikan hasil pengujian berdasarkan proses bootstrapping dengan menggunakan bantuan software PLS versi 3 . Hasil pengujian menunjukkan bahwa KSDM, PIA, dan PK adalah signifikan terhadap KPK pada tingkat keyakinan 5\%, sedangkan PTI memiliki hasil tidak signifikan pada tingkat keyakinan 5\%. Penelitian ini juga membuktikan bahwa KSDM, PTI, PIA, dan PK memiliki hasil yang tidak signifikan terhadap TPK pada tingkat keyakinan 5\%. Berdasarkan nilai path coefficient yang diperoleh maka persamaan dari model pengukuran (inner moded) penelitian ini disajikan sebagai berikut.

KPK $={ }_{\gamma 1} 2,605+{ }_{\gamma_{2}} 0,977+{ }_{\gamma_{3}} 2,267+{ }_{\gamma 4} 2,949+\varsigma$

TPK $={ }_{\gamma 5} 0,321+{ }_{\gamma 6} 1,530+{ }_{\gamma 7} 1,803+{ }_{\gamma 8} 1,891+\varsigma$

Tabel 5. Path coefficient

\begin{tabular}{|c|c|c|c|c|c|}
\hline & $\begin{array}{l}\text { Original } \\
\text { Sample } \\
\quad(\mathbf{O})\end{array}$ & $\begin{array}{c}\text { t-statistic } \\
\left({ }_{\mathrm{I}} \mathrm{O} / \mathrm{STDEV}_{\mathrm{I}}\right)\end{array}$ & p-value & Keterangan & Kesimpulan \\
\hline $\mathrm{KSDM} \rightarrow \mathrm{KPK}$ & 0,304 & 2,605 & 0,009 & Signifikan & $\mathrm{H}_{1}$ Diterima \\
\hline $\mathrm{PTI} \rightarrow \mathrm{KPK}$ & $-0,119$ & 0,977 & 0,329 & Tidak Signifikan & $\mathrm{H}_{2}$ Ditolak \\
\hline $\mathrm{PIA} \rightarrow \mathrm{KPK}$ & 0,283 & 2,267 & 0,024 & Signifikan & $\mathrm{H}_{3}$ Diterima \\
\hline $\mathrm{PK} \rightarrow \mathrm{KPK}$ & 0,366 & 2,949 & 0,003 & Signifikan & $\mathrm{H}_{4}$ Diterima \\
\hline $\mathrm{KSDM} \rightarrow \mathrm{TPK}$ & 0,059 & 0,321 & 0,748 & Tidak Signifikan & $\mathrm{H}_{5}$ Ditolak \\
\hline PTI $\rightarrow$ TPK & 0,197 & 1,530 & 0,127 & Tidak Signifikan & $\mathrm{H}_{6}$ Ditolak \\
\hline PIA $\rightarrow$ TPK & 0,270 & 1,803 & 0,072 & Tidak Signifikan & $\mathrm{H}_{7}$ Ditolak \\
\hline $\mathrm{PK} \rightarrow \mathrm{TPK}$ & 0,238 & 1,891 & 0,059 & Tidak Signifikan & $\mathrm{H}_{8}$ Ditolak \\
\hline \multicolumn{6}{|c|}{$\begin{array}{l}\text { Catatan: KSDM } \rightarrow \text { KPK }\left(\gamma_{1}\right) \text { adalah pengaruh KSDM terhadap KPK, KSDM } \rightarrow \text { TPK }\left(\gamma_{5}\right) \text { adalah pengaruh KSDM terhadap } \\
\text { TPK, PTI } \rightarrow \text { KPK }\left(\gamma_{2}\right) \text { adalah pengaruh PTI terhadap KPK, PTI } \rightarrow \text { TPK }\left(\gamma_{6}\right) \text { adalah pengaruh PTI terhadap TPK, PIA } \rightarrow \text { KPK } \\
\left(\gamma_{3}\right) \text { adalah pengaruh PIA terhadap KPK, PIA } \rightarrow \text { TPK }\left(\gamma_{7}\right) \text { adalah pengaruh PIA terhadap TPK, PK } \rightarrow \text { KPK }\left(\gamma_{4}\right) \text { adalah pengaruh } \\
\text { PK terhadap KPK, dan PK } \rightarrow \text { TPK }\left(\gamma_{8}\right) \text { adalah pengaruh PK terhadap TPK. }\end{array}$} \\
\hline
\end{tabular}

\section{Pembahasan}

Kualitas sumber daya manusia dan keandalan pelaporan keuangan. Hipotesis pertama (H1) menyatakan bahwa kualitas sumber daya manusia berpengaruh positif terhadap keandalan pelaporan keuangan. Tabel 5 menunjukkan bahwa koefisien jalur (path coefficient) dari kualitas sumber daya manusia memiliki nilai signifikan pada tingkat kepercayaan 5\% dengan nilai original sample sebesar 0.304. Hasil uji ini menunjukkan bahwa kualitas sumber daya manusia memiliki pengaruh positif terhadap keandalan pelaporan keuangan sehingga H1 dapat diterima. Secara empiris, hasil ini mengindikasikan bahwa peningkatan sumber daya manusia dalam Sub Bagian Akuntansi/Keuangan pada Pemerintah Kabupaten Sumbawa Barat telah dilakukan secara maksimal walaupun masih memiliki kendala berupa kompetensi pegawai yang belum sesuai dengan bidang akuntansi atau kurang optimalnya pelatihan-pelatihan terkait bidang akuntansi atau keuangan. Temuan penelitian ini konsisten dengan Andriani (2010), Winidyaningrum dan Rahmawati (2010), Mustafa et al. (2011), Hullah et al. (2012), Ariesta (2013), Sembiring (2013), Marda et al. (2014), Sari dan Witono (2014), Azlan et al. (2015), Fransiska et al. (2015), Kosegeran et al. (2016), Safitri (2016), Setianingrum (2016), Yusrawati dan Cahyanti (2016), dan Putra (2017). Sebaliknya, temuan penelitian ini tidak konsisten dengan Indriasari dan Nahartyo 
(2008), Arfianti dan Kawedar (2011), Rosalin dan Kawedar (2011), Rachmawati (2014), dan Prasetyo (2015).

Pemanfaatan teknologi informasi dan keandalan pelaporan keuangan. Hipotesis kedua ( $\mathrm{H} 2)$ menyatakan bahwa pemanfaatan teknologi informasi berpengaruh positif terhadap keandalan pelaporan keuangan. Tabel 5 menunjukkan bahwa koefisien jalur (path coefficient) dari pemanfaatan teknologi informasi memiliki nilai tidak signifikan pada tingkat $5 \%$ dengan nilai original sample sebesar -0,119. Hasil uji ini menunjukkan bahwa pemanfaatan teknologi informasi tidak berpengaruh terhadap keandalan pelaporan keuangan sehingga H2 tidak dapat diterima. Secara empiris, hasil ini mengindikasikan bahwa Pemerintah Kabupaten Sumbawa Barat belum memanfaatkan teknologi informasi dengan maksimal guna menjaga keandalan laporan keuangan daerah. Berdasarkan hasil pengamatan, Sub Bagian Penatausahaan Keuangan pada beberapa OPD masih memiliki peralatan komputer dalam menunjang operasional, belum terpasangnya jaringan internet untuk mendukung transfer data, dan belum optimalnya rutinitas pemeliharaan peralatan-peralatan yang ada. Temuan penelitian ini tidak konsisten dengan Indriasari dan Nahartyo (2008), Andriani (2010), Winidyaningrum dan Rahmawati (2010), Rosalin dan Kawedar (2011), Hullah et al. (2012), Ariesta (2013), Sembiring (2013), Sari dan Witono (2014), Azlan et al. (2015), Fransiska et al. (2015), Prasetyo (2015), Kosegeran et al. (2016), Safitri (2016), Setianingrum (2016), Yusrawati dan Cahyanti (2016), dan Putra (2017). Sebaliknya, temuan penelitian ini konsisten dengan Arfianti dan Kawedar (2011), Mustafa et al. (2011), Marda et al. (2014), dan Rachmawati (2014).

Pengendalian intern akuntansi dan keandalan pelaporan keuangan. Hipotesis ketiga (H3) menyatakan bahwa pengendalian intern akuntansi berpengaruh terhadap keandalan pelaporan keuangan. Tabel 5 menunjukkan bahwa koefisien jalur (path coefficient) dari pengendalian intern akuntansi memiliki nilai signifikan pada tingkat $5 \%$ dengan nilai original sample sebesar 0.283. Hasil uji ini menunjukkan bahwa pengendalian intern akuntansi memiliki pengaruh positif terhadap keandalan pelaporan keuangan sehingga $\mathrm{H} 3$ dapat diterima. Secara empiris, hasil ini mengindikasikan bahwa sistem pengendalian intern akuntansi telah terlaksana dengan baik di Pemerintah Kabupaten Sumbawa Barat. Adanya pengendalian yang dilakukan oleh Pemerintah Kabupaten Sumbawa Barat (misalnya rekonsiliasi laporan keuangan OPD secara rutin di awal bulan) terbukti efektif dapat mendeteksi kesalahan yang terjadi guna dilakukannya tindakan korektif atas laporan keuangan pemerintah daerah. Temuan penelitian ini konsisten dengan Indriasari dan Nahartyo (2008), Winidyaningrum dan Rahmawati (2010), Arfianti dan Kawedar (2011), Rosalin dan Kawedar (2011), Ariesta (2013), Sembiring (2013), Rachmawati (2014), Sari dan Witono (2014), Azlan et al. (2015), Prasetyo (2015), Kosegeran et al. (2016), Setianingrum (2016), Yusrawati dan Cahyanti (2016), dan Putra (2017). Sebaliknya, temuan penelitian ini tidak konsisten dengan Mustafa et al. (2011).

Pengawasan keuangan dan keandalan pelaporan keuangan. Hipotesis keempat (H4) menyatakan bahwa pengawasan keuangan berpengaruh positif terhadap keandalan pelaporan keuangan. Tabel 5 menunjukkan bahwa koefisien jalur (path coefficient) dari pengawasan keuangan memiliki nilai signifikan pada tingkat 5\% dengan nilai original sample sebesar 0.366 . Hasil uji ini menunjukkan bahwa pengawasan keuangan memiliki pengaruh positif terhadap keandalan pelaporan keuangan sehingga $\mathrm{H} 4$ dapat diterima. Secara empiris, hasil ini mengindikasikan bahwa pemerintah Kabupaten Sumbawa Barat telah menciptakan pengawasan yang efektif. Melalui pengawasan yang efektif atas pengelolaan keuangan daerah maka Pemerintah Kabupaten Sumbawa Barat mampu memberikan keyakinan bahwa informasi yang disajikan dalam pelaporan keuangan adalah benar atau valid sehingga menjamin keandalan penyajian informasi 
dalam laporan keuangan pemerintah daerah. Temuan penelitian ini konsisten dengan Mustafa et al. (2011), Marda et al. (2014), Azlan et al. (2015), Fransiska et al. (2015), Setianingrum (2016), dan Putra (2017). Sebaliknya, temuan penelitian ini tidak konsisten dengan Arfianti dan Kawedar (2011).

Kualitas sumber daya manusia dan ketepatan waktu pelaporan keuangan. Hipotesis kelima (H5) menyatakan bahwa kualitas sumber daya manusia berpengaruh positif terhadap ketepatan waktu pelaporan keuangan. Tabel 5 menunjukkan bahwa koefisien jalur (path coefficient) dari kualitas sumber daya manusia memiliki nilai tidak signifikan pada tingkat $5 \%$ dengan nilai original sample sebesar 0,059. Hasil uji ini menunjukkan bahwa kualitas sumber daya manusia tidak berpengaruh terhadap ketepatan waktu pelaporan keuangan sehingga H5 tidak dapat diterima. Berdasarkan pengamatan, pegawai yang ada di Pemerintahan Kabupaten Sumbawa Barat berlatar belakang pendidikan di bidang akuntansi masih belum memadai sehingga peraturan perundang-undangan yang mewajibkan OPD untuk menyelenggarakan akuntansi dan menyusun laporan keuangan masih belum tercapai secara optimal. Selain itu, kurangnya pemberdayaan sumber daya manusia dapat direfleksikan dengan belum optimalnya pelatihan-pelatihan yang berhubungan dengan bidang akuntansi dan pengelolaan keuangan daerah bagi para pegawai. Temuan penelitian ini tidak konsisten dengan Indriasari dan Nahartyo (2008), Arfianti dan Kawedar (2011), Mustafa et al. (2011), Ariesta (2013), Sembiring (2013), Sari dan Witono (2014), Prasetyo (2015), Kosegeran et al. (2016), Safitri (2016), dan Marlinawati dan Wardani (2018). Sebaliknya, temuan penelitian ini konsisten dengan Andriani (2010), Winidyaningrum dan Rahmawati (2010), Rosalin dan Kawedar (2011), dan Rachmawati (2014).

Pemanfaatan teknologi informasi
dan ketepatan waktu pelaporan
keuangan. Hipotesis keenam $(\mathrm{H} 6)$
menyatakan bahwa pemanfaatan teknologi

informasi berpengaruh positif terhadap ketepatan waktu pelaporan keuangan. Tabel 5 menunjukkan bahwa koefisien jalur (path coefficient) dari pemanfaatan teknologi informasi memiliki nilai tidak signifikan pada tingkat $5 \%$ dengan nilai original sample sebesar 0,197. Hasil uji ini menunjukkan bahwa pemanfaatan teknologi informasi tidak berpengaruh terhadap ketepatan waktu pelaporan keuangan sehingga H6 tidak dapat diterima. Secara empiris, hasil ini mengindikasikan bahwa Pemerintah Kabupaten Sumbawa Barat belum secara optimal mengintegrasikan teknologi informasi pada pelaksanaan tugas-tugas akuntansi guna mencapai ketepatan waktu pelaporan keuangan. Hal ini juga mengindikasikan bahwa Pemerintah Daerah Kabupaten Sumbawa Barat melalui Badan Pengelola Keuangan Daerah (BPKD) belum optimal dalam memanfaatkan perangkat komputer dalam rangka pemrosesan dan penyimpanan data keuangan termasuk publikasi informasi pada situs yang dimiliki. Selain itu, belum optimalnya intensitas jadwal perawatan atau pemeliharaan bagi perangkat teknologi masih merupakan kendala teknis bagi OPD. Temuan penelitian ini tidak konsisten dengan Indriasari dan Nahartyo (2008), Andriani (2010), Winidyaningrum dan Rahmawati (2010), Arfianti dan Kawedar (2011), Rosalin dan Kawedar (2011), Ariesta (2013), Sembiring (2013), Trisaputra (2013), Sari dan Witono (2014), Prasetyo (2015), Kosegeran et al. (2016), dan Safitri (2016). Sebaliknya, temuan penelitian ini konsisten dengan Mustafa et al. (2011), Rachmawati (2014), dan Marlinawati dan Wardani (2018).

Pengendalian intern akuntansi dan ketepatan waktu pelaporan keuangan. Hipotesis ketujuh (H7) menyatakan bahwa pengendalian intern akuntansi berpengaruh positif terhadap ketepatan waktu pelaporan keuangan. Tabel 5 menunjukkan bahwa koefisien jalur (path coefficient) dari pengendalian intern akuntansi memiliki nilai tidak signifikan pada tingkat 5\% dengan nilai original sample sebesar 0,270. Hasil uji ini menunjukkan bahwa pengendalian intern akuntansi tidak berpengaruh terhadap 
ketepatan waktu pelaporan keuangan sehingga H7 tidak dapat diterima. Secara empiris, hasil ini mengindikasikan bahwa Pemerintah Kabupaten Sumbawa Barat belum optimal melaksanakan sistem pengendalian intern akuntansi yang efisien dan efektif. Adanya pengendalian intern akuntansi dari setiap unit organisasi atau OPD yang ada di lingkungan Pemerintah Kabupaten Sumbawa Barat akan mewujudkan ketepatan waktu dalam laporan keuangan dikarenakan dalam pengendalian intern akuntansi yang dijalankan dengan tepat pada setiap OPD akan mewujudkan kualitas laporan keuangan yang baik sehingga dalam penyajiannya dapat tepat waktu. Temuan penelitian ini tidak konsisten dengan Sembiring (2013), Rachmawati (2014), Sari dan Witono (2014), Kosegeran et al. (2016), dan Marlinawati dan Wardani (2018). Sebaliknya, temuan penelitian ini konsisten dengan Mustafa et al. (2011), dan Rosalin dan Kawedar (2011).

\section{Pengawasan keuangan dan} ketepatan waktu pelaporan keuangan. Hipotesis kedelapan (H8) menyatakan bahwa pengawasan keuangan berpengaruh terhadap ketepatan waktu pelaporan keuangan. Tabel 5 menunjukkan bahwa koefisien jalur (path coefficient) dari pengawasan keuangan memiliki nilai tidak signifikan pada tingkat $5 \%$ dengan nilai original sample sebesar 0,238. Hasil uji ini menunjukkan bahwa pengawasan keuangan tidak berpengaruh terhadap ketepatan waktu pelaporan keuangan sehingga $\mathrm{H} 8$ tidak dapat diterima. Secara empiris, hasil ini mengindikasikan bahwa Pemerintah Kabupaten Sumbawa Barat belum optimal menciptakan pengawasan keuangan yang efektif sehingga belum menciptakan pelaporan keuangan pemerintah daerah yang tepat waktu. Temuan penelitian ini tidak konsisten dengan Mustafa et al. (2011), dan Trisaputra (2013) tetapi masih konsisten dengan Arfianti dan Kawedar (2011).

\section{Kesimpulan dan saran}

\section{Kesimpulan}

Berdasarkan hasil dan pembahasan maka dapat disimpulkan bahwa kualitas sumber daya manusia, pengendalian intern akuntansi, dan pengawasan keuangan berpengaruh positif dan signifikan terhadap keandalan pelaporan keuangan Pemerintah Kabupaten Sumbawa Barat sebaliknya penelitian ini menemukan bahwa seluruh variabel independen tidak signifikan berpengaruh terhadap ketepatan waktu pelaporan keuangan Pemerintah Kabupaten Sumbawa Barat. Implikasi teoritis dalam penelitian ini adalah bahwa teori keagenan (agency theory) dapat menjelaskan hubungan antara tujuan dengan perilaku individu dari sudut pandang keandalan laporan keuangan dari Pemerintah Kabupaten Sumbawa Barat.

Individu yang memahami tujuan apa yang dilakukan maka akan mempengaruhi kinerja. Implikasi teoritis lainnya adalah teori kepatuhan (compliance theory) tidak dapat diterapkan pada Pemerintah Kabupaten Sumbawa Barat khususnya dari sudut pandang ketepatwaktuan pelaporan keuangan yang cenderung disebabkan karena pemberdayaan sumber daya manusia, pemanfaatan teknologi informasi, pengendalian intern akuntansi, dan pengawasan keuangan yang belum sinergis.

Penelitian ini masih memiliki keterbatasan yang didasarkan pada model penelitian yang digunakan, dimana tingkat kekuatan prediksi dari model struktural mempunyai nilai yang masih rendah sehingga mengindikasikan bahwa masih terdapat variabel lainnya yang mempengaruhi keandalan dan ketepatan waktu pelaporan keuangan. Selain itu, penggunaan metode survey melalui kuesioner memungkinkan karakteristik dan pendapat responden tidak terlihat secara nyata melalui objek penelitian dan jumlah responden yang terbatas.

\section{Saran}

Bagi pihak peneliti selanjutnya dalam bidang sama agar dapat mengembangkan variabel penelitian dengan melihat faktorfaktor lain yang berpengaruh terhadap keandalan dan ketepatan waktu pelaporan keuangan, seperti komitmen organisasi, good government governance, gaya kepemimpinan, dan tingkat pendidikan. Selain itu, penelitian selanjutnya dapat mengembangkan dan 
menggunakan pendekatan eksperimen atau pendekatan kualitatif untuk mendapatkan pendapat responden yang spesifik, serta memperluas objek penelitian dan menambah jumlah responden agar memperoleh hasil yang lebih baik.

\section{Ketersediaan data}

Data penelitian ini dapat diakses secara terbuka pada dokumen pendukung artikel (supplementary file) dan Repositori Ilmiah Nasional Lembaga Ilmu Pengetahuan Indonesia (RIN-LIPI) dengan link https://hdl.handle.net/20.500.12690/RIN/ 9J2NWG

\section{Daftar pustaka}

Andriani, W. (2010). Pengaruh kapasitas sumber daya manusia dan pemanfaatan teknologi informasi terhadap keterandalan dan ketepatwaktuan pelaporan keuangan pemerintah daerah (Studi pada Pemerintah Daerah Kabupaten Pesisir Selatan). Jurnal Akuntansi dan Manajemen, 5(1), 6980. http://repo.polinpdg.ac.id/364/1/316-3081-PB.pdf.

Arfianti, D., \& Kawedar, W. (2011). Analisis faktor-faktor yang mempengaruhi nilai informasi pelaporan keuangan pemerintah daerah (Studi pada satuan kerja perangkat daerah di Kabupaten Batang). Skripsi.

http://eprints.undip.ac.id/29808/1/Artikel Jurn al1.pdf

Ariesta, F. (2013). Pengaruh kualitas sumber daya manusia, pemanfaatan teknologi informasi dan pengendalian intern akuntansi terhadap nilai informasi pelaporan keuangan pemerintah daerah (Studi pada satuan kerja perangkat daerah di Kabupaten Pasaman Barat). Jurnal Akuntansi, 1(1),

52-81.

http://ejournal.unp.ac.id/students/index.php/a $\mathrm{kt} /$ article/view/52.

Azlan, M., Herwanti, T., \& Pituringsih, E. (2015). Pengaruh kualitas sumber daya manusia, pemanfaatan teknologi informasi, pengendalian intern akuntansi, dan pengawasan keuangan daerah terhadap keandalan laporan keuangan daerah pada SKPD pemerintah Kabupaten Lombok Timur. Jurnal Akuntansi Aktual 3(2), 188-198. http://journal2.um.ac.id/index.php/jaa/article/ view $/ 7178$

Fransiska, Azlina, N., \& Susilatri. (2015). Pengaruh sumber daya manusia, pengawasan keuangan daerah, pemanfaatan teknologi informasi, dan komitmen organisasi terhadap keandalan pelaporan keuangan pemerintah daerah (Studi pada satuan kerja perangkat daerah Kabupaten Labuhan Batu). Jurnal Online Mabasiswa Fakultas Ekonomi 2(2), https://iom.unri.ac.id/index.php/JOMFEKON Larticle/view/9124.
Ghozali, I., \& Latan, H. (2015). Partial Least Squares: Konsep, teknik, aplikasi menggunakan PLS 3.0 untuk penelitian empiris. Semarang: BP Universitas Diponegoro.

Haryanto, Sahmuddin, \& Arifuddin. 2007. Akuntansi sektor publik. Semarang: Badan Penerbit Universitas Diponegoro.

Hullah, A. R., Pangemanan, S., Tangkuman, S., \& Budiarso, N. (2012). Pengaruh sumber daya manusia dan pemanfaatan teknologi informasi terhadap keterandalan pelaporan keuangan pada pemerintahan Sulawesi Utara. Jurnal Riset Akuntansi dan Auditing, 3(2), 9-21. https://doi.org/10.35800/ijs.v3i2.1046

Indriasari, D., \& Nahartyo, E. (2008). Pengaruh kapasitas sumber daya manusia, pemanfaatan teknologi informasi dan pengendalian intern akuntansi terhadap nilai informasi pelaporan keuangan pemerintah daerah (Studi pada Pemerintah Kota Palembang dan Kabupaten Ogan Ilir). Simposium Nasional Akuntansi XI. http://digilib.mercubuana.ac.id/manager/t!@,file artikel abstrak/Isi Artikel 649299136533.pdf.

Jensen, M., \& Meckling, W. (1976). Theory of the firm: Managerial behavior, agency, and ownership structure. Journal of Financial Economics, 3(4), 305$360 . \quad$ https://doi.org/10.1016/0304405X(76) $90026-X$

Kelman, H. C. (1958). Compliance, identification, and internalization: Three processes of attitude change. Journal of Conflict Resolution, 2(1), 51-60. https://scholar.harvard.edu/hckelman/publicati ons/compliance-identification-andinternalization-three-processes-attitude-change

Kosegeran, A. I., Kalangi, L., \& Wokas, H. (2016). Analisis faktor-faktor yang mempengaruhi keandalan dan ketepatan waktu pelaporan keuangan SKPD pada pemerintah Kabupaten Minahasa Tenggara. Jurnal Accountability 5(2), 178-190. https://doi.org/10.32400/ja.14434.5.2.2016.178190.

Marda, G. S., Satriawan, R. A., \& Supriono. (2014). Pengaruh sumber daya manusia, pemanfaatan teknologi informasi, dan pengawasan keuangan daerah terhadap keandalan pelaporan keuangan pemerintah Kota Dumai. Jurnal Online Mabasiswa Fakultas Ekonomi, 1(1), 1-15. https://iom.unri.ac.id/index.php/JOMFEKON article/view/3126.

Mardiasmo. (2002). Akuntansi Sektor Publik, Edisi Pertama. Yogyakarta: Penerbit Andi.

Marlinawati, \& Wardani, D. K. (2018). Pengaruh kualitas sumber daya manusia, pemanfaatan teknologi informasi dan sistem pengendalian intern terhadap ketepatan waktuan pelaporan keuangan pemerintah desa. Jurnal Kajian Bisnis, 26(2), 131 143.

http://jurnal.stieww.ac.id/index.php/ikb/article $/$ view/106

Mustafa, H., Fauziati, P., \& Frinola, A. (2011). Pengaruh kualitas sumber daya manusia, pemanfaatan teknologi informasi, sistem pengendalian intern, dan pengawasan keuangan daerah terhadap keandalan dan ketepatan waktu pelaporan keuangan pemerintah daerah (Studi empiris pada pemerintah Kota Padang). Universitas Bung Hatta. http://ejurnal.bunghatta.ac.id/index.php?journal 
$=J$ FEK\&page $=$ article\&op $=$ viewFile\&path $\|=79$ 78\&path $\|=6735$

Prasetyo, A. R. (2015). Pengaruh kapasitas sumber daya manusia, pemanfaatan teknologi informasi, pengendalian interen akuntansi dan Good Corporate Governance terhadap keterandalan dan ketepatanwaktuan pelaporan keuangan pemerintah (Studi empiris pada 32 satuan kerja di POLDA Jambi). Jurnal Akuntansi dan Keuangan Unja, 1(1), 37-53. https://onlinejournal.unja.ac.id/jaku/article/view/2379

Putra, R. A. (2017). Pengaruh kualitas sumber daya manusia, pemanfaatan teknologi informasi, sistem pengendalian intern akuntansi, pengawasan keuangan daerah, dan komitmen organisasi terhadap keandalan pelaporan keuangan pemerintah (Studi pada satuan kerja perangkat daerah Kabupaten Bengkalis). Jurnal Online Mahasiswa Fakultas Ekonomi, 4(1), 10371050.

https://jom.unri.ac.id/index.php/JOMFEKON Larticle/download/12608/12250

Rachmawati, A. (2014). Pengaruh kapasitas sumber daya manusia, pemanfaatan tekhnologi informasi, komitmen organisasi, dan pengendalian intern akuntansi terhadap keterandalan dan Ketepatwaktuan pelaporan keuangan pemerintah daerah (Studi pada Dinas Pendapatan, Pengelolaan Keuangan dan Aset Daerah Kabupaten Boyolali). Skripsi.

http://eprints.ums.ac.id/32082/9/NASKAH $\% 20$ PUBLIKASI.pdf

Rosalin, F., \& Kawedar, W. (2011). Faktor-faktor yang mempengaruhi keandalan dan timeliness pelaporan keuangan Badan Layanan Umum (Studi pada BLU di Kota Semarang). Skripsi. http://eprints.undip.ac.id/29439/1/jurnal.pdf

Safitri, H. (2016). Pengaruh kualitas sumber daya manusia, dan pemanfaatan teknologi informasi terhadap keandalan dan ketepatwaktuan pelaporan keuangan pemerintah daerah (Studi pada satuan kerja perangkat daerah Kabupaten Lumajang). https://docplayer.info/54703961-Hudalila-safitripengaruh-kualitas-sumber-daya-manusia-danpemanfaatan-teknologi-informasi.html

Sari, S. P., \& Witono, B. (2014). Keterandalan dan ketepatwaktuan pelaporan keuangan daerah ditinjau dari sumber daya manusia, pengendalian Internal, dan pemanfaatan teknologi informasi. Seminar Nasional dan Call For Paper (Sancall 2014). Research Methods and Organizational Studies. 418-425. https://publikasiilmiah.ums.ac.id/handle/11617/4 $\underline{710}$

Sembiring, F. L. (2013). Pengaruh kualitas sumber daya manusia, pemanfaatan tekhnologi informasi, dan system pengendalian intern terhadap keandalan dan ketepatwaktuan pelaporan keuangan pemerintah (Studi empiris pada pemerintah Kota Padang). Jurnal Akuntansi, 1(1), 1-10. http://ejournal.unp.ac.id/students/index.php/akt Larticle/view/92

Setianingrum, D. (2016). Pengaruh kualitas sumber daya manusia, pemanfaatan teknologi informasi, pengendalian intern akuntansi, dan pengawasan keuangan daerah terhadap keandalan dan ketepatan waktu pelaporan keuangan (Studi pada dinas pendapatan, pengelolaan keuangan, dan aset daerah Karang Anyar). Skripsi. Universitas
Muhammadiyah

Surakarta. http://eprints.ums.ac.id/41043/1/NASKAHPUB LIKASIDESY.pdf

Trisaputra, A. (2013). Pengaruh Pemanfaatan Teknologi Informasi dan Pengawasan Keuangan Daerah Terhadap Ketepatwaktuan Pelaporan Keuangan Pemerintah Daerah (Studi Empiris pada SKPD Pemerintah Provinsi Sumatera Barat). Skripsi. Jurnal Akuntansi, 1(3), http://ejournal.unp.ac.id/students/index.php/akt $\angle$ article/view $/ 680$

Winidyaningrum, C., \& Rahmawati. (2010). Pengaruh sumber daya manusia dan pemanfaatan teknologi informasi terhadap keterandalan dan ketepatwaktuan pelaporan keuangan pemerintah daerah dengan variabel intervening pengendalian intern akuntansi (Studi empiris di Pemda SUBOSUKAWONOSRATEN). Simposium Nasional Akuntansi XIII. 13-14. https://stiepena.ac.id/wpcontent/uploads/2011/11/ASP 18.pdf

Yosa. (2010). Pengawasan keuangan. www.itjendepdagri.go.id

Yusrawati, \& Cahyanti, N. (2016). Pengaruh kapasitas sumber daya manusia, pemanfaatan teknologi informasi, dan pengendalian intern akuntansi terhadap keterandalan pelaporan keuangan pemerintah daerah (Studi pada SKPD Kabupaten Rokan Hilir). Jurnal Ekonomi KIAT, 26(1). https://journal.uir.ac.id/index.php/kiat/article/vie $\underline{\mathrm{w} / 3020}$ 